\section{Advances in post-fermented wine clarification by centrifugal technology}

\author{
Giacomo Costagli, ${ }^{1}$ Carole Rapilly, ${ }^{1}$ \\ Marco Franzoso, ${ }^{1}$ Mikael Sjoberg, ${ }^{2}$ \\ Luca Bonetti, ${ }^{3}$ Gian Maria Ciman, ${ }^{3}$ \\ Francesco Lonardi ${ }^{3}$
}

${ }^{1}$ Alfa Laval S.p.A-Market Unit Food, Beverage \& Olive Oil, Calenzano (FI), Italy; ${ }^{2}$ Alfa Laval Tumba AB-Food Technology, Tumba, Sweden; ${ }^{3}$ PerfectWine S.r.I., Spin Off of Verona University, San Pietro in Cariano (VR), Italy

\section{Abstract}

Wine clarification processes are deeply determined by complex interaction of wine constituents and application of available technologies as well as use of fining agents. Among others, centrifuge is a consolidated technique applied for many separation duties in the winery. Important advances on improvement of the performance of centrifugal technology have beeen focused on gentle wine treatment, minimal dissolved oxygen and significant reduction of energy consumption helping to dispel old beliefs on a technique considered to be traditional. This paper reviews the development of technology and recent advances on centrifuge improvement and aims to show, through field experimental observation, the importance of removing a portion of particles responsible of haze in the light of very low level of dissolved oxygen and complementarity of alternative recent techniques of wine filtration like cross-flow microfiltration.

\section{Introduction}

In June 1878 to Dr. Gustaf de Laval was granted the patent of The Centrifuge for the separation of cream from milk. The introduction of centrifuge generates a revolution in a wide range of industrial application and currently the technology is applied throughout many manufacturing industries with different centrifuge designs adapted to particular uses. ${ }^{1}$ Sedimentation centrifuge with radial solidsejecting are the commonest, and today the most important applications are production of milk and other beverages, including wine, and purification of fuel and lube oil on ships. ${ }^{2}$

The use of centrifugal technology for must and wine clarification was successfully tested for the first time in France at the beginning of
$1900 .^{3} \mathrm{~A}$ very positive experience and forecasting great success for the future of techniques was quickly extended also to Italy. ${ }^{4}$ Simultaneously some authors, at the very beginning, advanced doubts on the quality effect, due to potential oxygen contact effect, probably caused to the initial design of the machine. ${ }^{3}$ The centrifuge's design was developed very quickly in mid-1900 as well as the introduction of different manufacturer. A better design was created to protect oxygen, and the centrifugation applied to wine industry was used not only in Europe but also in the United States, to improve the capacity to treat important volumes of product in continuous. At that time, centrifugal technology was tested with fermented and fortified wine with important conclusions, which put in evidence the possibility to make speedy clarification of young wine, eliminating further rackings and difficulties encountered on filtration of chilled wine when the centrifuge is employed instead. ${ }^{5}$ The authors wants to put on focus the importance of the combined use of fining agents, but remarks the positive economic advantages of centrifuge's use to improve and optimize the subsequent use of pad filtration. ${ }^{5,6}$ During the same period, Nasledov $(1951)^{7}$ indicated different application of the centrifuge in the cellar, with detailed description of installation and flow chart for juice or young wine clarification and in combination of polishing filter on wine ready to bottle.

During the second half of 1900, and until today, the use of centrifuge in wine industry was going to be consolidated and described, in different application, into winemaker handbooks. ${ }^{8,11-12}$ Today centrifugal technology still has a crucial importance in the wine industry, depending on scale of production, for speedy and sustainability of processing with a particular focus on must and wine clarification.

Generally speaking, centrifuges are classified in sedimentation and filter centrifuges as per exhaustive description of Sokolov (1971). ${ }^{13}$ Among sedimentation centrifuges, the disk stack, which discharges intermittently and radially, is the one used in the wine industry. Process function is based on the fast rotating bowl (speed is about $6000 \mathrm{rpm}$ ) in which the separation takes place (Figure 1). The incoming liquid (feed) enters in the centrifuge via the inlet (a) where it is spun up to the speed of the centrifuge. The feed is thereafter led radially outward in the distributor (b) and it is distributed to the disk stack (c). The disk stack consists of closely spaced conical discs. In order to have an efficient centrifuge, a large surface area is needed and about two hundreds discs are used. The liquid is continuously separated from the sediment as it goes towards the centre of the bowl. When the separated liquid leaves the disk stack, it raise upwards and flow out of the bowl through a
Corresponding author: Giacomo Costagli, Alfa Laval S.p.A.-Market Unit Food, Beverage \& Olive Oil, via delle Calandre 53, 50041 Calenzano (FI), Italy.

Tel +39.0392 .7041390 .

E-mail: giacomo.costagli@alfalaval.com

Key words: Wine; Clarification; Centrifuge; Separation; Alfa Laval.

Contribution: the authors contributed equally.

Conflict of interest: GC, CR, MF, MS are employees of Alfa Laval company, which provided part of the materials used in this study.

Acknowledgments: the authors would like to thank Mr. Furio Battellini of cellar Riva del Garda, Mr. Donato Giuliani of cellar Cantine Teanum, Mr. Sébastian Tomasoni of cellar Les Vignerons d'Argeliers.

Received for publication: 25 July 2016 .

Revision received: 11 November 2016.

Accepted for publication: 14 November 2016.

This work is licensed under a Creative Commons Attribution 4.0 License (by-nc 4.0).

(C) Copyright G. Costagli et al., 2016

Licensee PAGEPress, Italy

Wine Studies 2016; 5:6201

doi:10.4081/ws.2016.6201

centripetal pump known as paring disk (d). The paring disk converts the kinetic energy of the rotating liquid, and discharges it under pressure. Backpressure should be applied and regulated (from 2 to 9 bar) by a specific device on liquid outlet according to throughput maintain the bowl full of liquid in order to limit its aeration and to avoid turbulences which can have bad impact on separation efficiency. Separated sediment, which is heavier than liquid, is forced towards the periphery of the bowl and collected in the sediment space (e) outside the disc stack. Discharge of sediments takes place through a number of ports in the bowl wall. Discharge occurs in an intermittent adjustable way thanks to the sliding bowl bottom. The sliding bowl bottom is forced upwards against a seal ring by a specific liquid force acting on its underside.

Bowl designs of disk stack centrifuge with schematic representation of liquid flow, used today in wine industry, are schematically showed in Figure 2. The most common traditional design is the top feed open bowl (Figure $2 A)$. The nonrotating feed enters in an open chamber in which the product is accelerated. That design has been improved by Alfa Laval through the introduction of a special inlet geometry (with introduction of disk inlet) which dissipates the energy over a larger volume and decreases the shear forces. ${ }^{14}$ The 
introduction of a new inlet design improved significantly wine clarification with better separation. The same bowl design has also the possibility to set up a liquid or mechanical seal at the liquid outlet. To insert a mechanical seal in an open top feed bowl gives the possibility to reduce the contact with air and makes possible the clarification of sparkling wines, avoiding loss of carbon dioxide. In this case, despite of mechanical seal, we are speaking of semi-open machine where there is still a contact with air in the centre of the bowl.

The alternative to the top feed open bowl is the fully hermetic bottom feed disk stack centrifuge design (Figure 2B). Feed the wine from bottom through a hollow spindle, gives a very gentle and smooth acceleration avoiding completely the air entrainment. Air contact and entrainment is totally avoided also at the outlet level. Tightness makes the bottom feed design the ideal one for sparkling wine clarification avoiding carbon dioxide loss. The combination of gentle product treatment and the use of impeller pump, rather than paring disk, gives to the bottom feed design centrifuge also the important advantage of energy saving, up to $50 \%$, with respect to the traditional of top feed centrifuge. An example of hermetic centrifuge module is showed in Figure 3.

Identification of proper technology for wine clarification as to take in consideration the composition of haze or raw wine. Haze of raw wine could be characterized by insoluble particles as fine dust, small fibre of grape skin, yeast or bacteria that remain in suspension. Other source of haze is also due to partially soluble particles as fine tartrate crystals, proteins and polysaccharides partially soluble, as well as finely dispersed precipitates of large-molecular-weight tannin materials, that are often combined with some proteinaceous components. ${ }^{11}$ Other authors propose a classification of individual compounds responsible of raw wine haze by their size and grouped in three categories as particles, colloids and solutes (Table 1)..$^{15}$ Because of their size, wine particles and, partially, colloids aggregates, are the main responsible of haze, potentially removed in a centrifugation process. Between particles, yeast are micro-organisms responsible of alcoholic fermentation with a size between 2 and $10 \mu \mathrm{m}$. Bacteria are another category of particles and also are micro-organisms with a very important role for wine quality. Lactic acid bacteria, responsible of malolactic fermentation, and acetic acid bacteria are the two most important types. Acetic acid bacteria are undesirable and responsible of wine spoilage. Bacteria are small cells forming pairs of chain with size of around $1 \mu \mathrm{m}$ or less, until $0.5 \mu \mathrm{m}$ minimum. ${ }^{16-18}$

Tartrate crystals represent an additional kind of particles. Tartrates are the result of tartaric acids' salt crystallization when wine is submitted to low temperature, also after bottling. Stabilization is required by cold or other alternative techniques, as ion exchange, electro-dialysis, or by the addition of some coadjuvant. ${ }^{17}$

Colloidal aggregates are the result of the agglomeration of the macromolecules of wines (mainly phenolic compounds, polysaccharides and proteins). They are responsible for most physicochemical disorders and deposits in wines, due to their instability and the exact composition of these aggregates, the mechanism involved and the parameters influencing the aggregations are not completely known yet and missing much information about this topic. ${ }^{11}$

Besides of individual components, formation of haze is also strictly related to physicochemical variables and interaction between components as polysaccharides complex, proteins and phenolic substance. ${ }^{18-20}$

The aim of fining and clarification is to remove suspended and colloidal particles as well as unstable proteins or other macromolecules that can lather denature or aggregate and make the wine appear hazy once bottled. ${ }^{21}$ On top of the use of fining agents, the wine makers could choose to clarify wine by technologies considered traditional as sedimenta-



(A) tion, centrifugation, filtration on plates, diatomaceous earth filtration or by recent innovative filtration technologies like cross flow microfiltration. ${ }^{8}$ Separation duties and benefits of centrifuge techniques applied to post-fermented wine clarification are listed in Table 2.



Figure 1. Cross-section of bowl of a disk stack centrifuge: (a) inlet; (b) distributor; (c) disk stack; (d) paring disk; (e) sediment space. Courtesy of Alfa Laval AB, Tumba, Sweden.

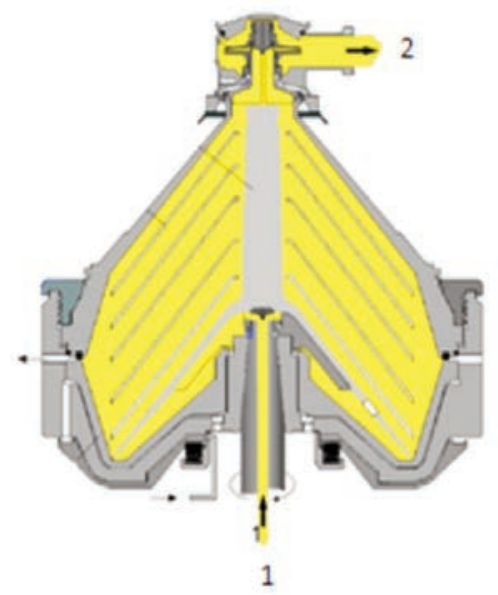

(B)

Figure 2. Cross-section of different designs of bowl of disk-stack centrifuges used for wine clarification: A) top feed open bowl; B) bottom feed hermetic bowl. 1=feed inlet; $2=$ clarified product outlet. Courtesy Alfa Laval AB, Tumba, Sweden.

Table 1. Raw wine compounds responsible of haze, classified by their size.

\begin{tabular}{lcc} 
Compound & Description & Sine \\
Particles & $\begin{array}{r}\text { Microorganisms (yeast and bacteria chains), } \\
\text { coll debris, colloidal aggregates and potassium tartrate crystals }\end{array}$ & $>1 \mu \mathrm{m}$ \\
Polysaccharides, proteins, polymerized & $>1 \mathrm{~nm}<1 \mu \mathrm{m}$ \\
\hline Solutes & $\begin{array}{l}\text { phenolic compounds and colloidal aggregates } \\
\text { Ions, salts, organic acids and phenolic compounds }\end{array}$ & $<1 \mathrm{~nm}$ \\
\hline
\end{tabular}


Applied research on centrifugal technology for wine industry is very limited and sometimes literature still reportes the centrifuge in the cellar as one of the cause of significant wine oxygen enrichment between enological techniques, without considering the continue and progressive improvement of centrifuge's design for a gentle treatment and for air protection. ${ }^{22,23}$ The purpose of that paper is to investigate the efficiency of clarification in light of the latest design innovation of centrifuge and complementarity of alternative recent techniques such as microfiltration.
NF400 with a swing-out rotor $(4 \times 100 \mathrm{~mL})$ with a diameter of $150 \mathrm{~mm}$. Microorganism content were measured ad bacterial count through WL Nutrient Agar earth. Filterability index were measured by Gibertini Mastermind ${ }^{\circledR}$ QFT. Total polyphenols were measured by Folin Ciocalteau and total colloids through the method based on the property of colloids to precipitate in alcoholic-acid environment. Finally, we calculated the increase of dissolved oxygen as the difference between the oxygen concentration measured before and immediately after the centrifugation through
Nomacorc NOMASens 02 Trace v2. All data are average of three replicates and standard deviation was calculated.

\section{Results and Discussion}

In all observation fields, centrifugal treatment does not affect acidity (total or volatile) $\mathrm{pH}$, alcohol, sugars and extract content, including the content of specific acids as malic, tartaric and lactic (data not showed). Results are

\section{Materials and Methods}

We tested five different kind of wines described on Table 3 and identified with references letters from A to E. All wines object of experimental observation was properly homogenised before taking sample and centrifugation or filtration. Clarification has been carried out with disk stack centrifuges Alfa Laval models Clara 200G (top feed open), Clara 200S (top feed hermetic seal) and Clara 601 (bottom feed full hermetic) and with tubular ceramic tangential filter Della Toffola CFKN with a surface of $65 \mathrm{~m}^{2}$ and microfiltration of $0.2 \mu \mathrm{m}$. All parameters were measured before and immediately after centrifugation. Analytical parameters like acidity (total and volatile), $\mathrm{pH}$, alcohol, sugars and extract content, including the content of specific acids as malic, tartaric and lactic were analysed with a Foss WineScan FT 120. Suspended solids (in volume) were measured by spin test at 5000 rpm for 5 minutes with centrifuge NUVE



Figure 3. Alfa Laval hermetic disk bowl centrifuge model Clara 250 for still and sparkling wine clarification. Courtesy of Alfa Laval AB, Tumba, Sweden.

Table 2. Description and benefits of centrifugal technology utilization on post-fermented wine clarification.

\begin{tabular}{|c|c|c|}
\hline Separation duty & Wine type & Description and benefits \\
\hline Alcoholic fermentation interruption ${ }^{9}$ & All, including sweet & Fast removal of yeast with stabilization of fortified/sweet wine \\
\hline Clarification after first fermentation & Young still and base for sparkling & $\begin{array}{l}\text { Fast separation of died yeast and unwished alive yeast } \\
\text { to avoid production of } \mathrm{H}_{2} \mathrm{~S} \text { when settling on lees; } \\
\text { wine clarification for malolactic fermentation improvement } \\
\text { (removal of yeast and partial removal of bacteria) } \\
\text { to improve culture or development of malolactic acid bacteria; } \\
\text { wine clarification for tartaric stabilization improvement } \\
\text { by removal of complex agents, inhibitors of crystallization } \\
\text { or fouling reduction when electrodyalisis is used }\end{array}$ \\
\hline Clarification after second fermentation ${ }^{9}$ & Sparkling & Particles removal under isobarometric conditions \\
\hline Clarification after tartaric stabilization & All & Removal of tartrate crystal produced during tartaric stabilization \\
\hline Polishing prior to bottling & Still and sparkling & $\begin{array}{l}\text { Reduction of turbidity; } \\
\text { increase capacity of cross flow filtration by up to } 75 \% \\
\text { (by removal of complex agents, generating high fouling) }\end{array}$ \\
\hline Protein stabilization & White still & $\begin{array}{c}\text { With inline dosing of bentonite, fast protein stabilization } \\
\text { and removal of deposit }\end{array}$ \\
\hline Biologic stabilization & All & $\begin{array}{l}\text { Fast removal of Brettanomyces when population } \\
\text { increase is detected }\end{array}$ \\
\hline Quick separation after fining ${ }^{9}$ & All & $\begin{array}{l}\text { Separation of the wine from the lees or deposits coming from the } \\
\text { addition of clarifying agents, deposited at the bottom of the container }\end{array}$ \\
\hline
\end{tabular}


in line with the expectations, due to the fact that centrifuge physical removes a portion of suspended solids without affect chemical composition. Compounds responsible of haze were measured before and immediately after centrifugation in the different kinds of wine listed in Table 3. In all the cases considered in our experiment fields, the suspended solids (in volume) were removed to a quantity minor than $0.1 \%$ by centrifuge, independently to bowl design and operational parameter. The removal of suspended solids reflects reduction of turbidity in all observed cases (Table 4). Depending on the kind of wine and different operational condition, turbidity reduction by centrifuge is from a minimum of $94 \%$ to a maximum of $99.7 \%$ for the majority of wines. Wine type E, with a very low initial turbidity compared to other observed cases, bring out a reduction of $71.7 \%$ (Tables 3 and 4 ). As expected, increase of flow rate in most of observed cases (wine type A-D) is corresponding with a slightly increase of turbidity at outlet (Table 4) due to a decrease of efficiency depending on Sigma factor $(\Sigma)$ and G-number of each centrifuge used for test. We consider solids separable with a wine centrifuge all suspended solids with a dimension bigger than $0.5 \mu \mathrm{m}$ and a density higher than the density of liquid phase. Based on particle dimensions, quantity and characteristics, the optimum clarification efficiency must be found in the centrifuge at the right flow rate: clarification efficiency is increased by reduction of flow rate.

Variation of backpressure doesn't bring out regular trend on the variation of turbidity reduction in all experiment fields (data not showed). A further significant effect of centrifugation is the microorganisms' removal. Depending on different kind of wine, reduction of bacterial count after centrifugation was from a minimum of $64 \%$ to a maximum of $98 \%$ (Tables 3 and 4). In all our observation, the variation of bacterial count removal cannot be related to flow rate variation (Table 3), as reported in the literature, ${ }^{3}$ or to counter pressure variation (data not showed).

Recent introduction and constant improvement of cross-flow microfiltration technique have changed significantly the scenario of wine clarification, and today are considered able to offer multiple advantages, as elimination of earth use with positive consequences for the environment and combination of multi- ple steps of clarification/filtration in a single continuous step. ${ }^{24,25}$ However the implementation of cross flow microfiltration in wine industry is still limited by important fouling phenomena with consequent problems to get economical flux rate and product quality. ${ }^{15,24-27}$ Our field experience with red wine type $\mathrm{E}$ (Table 3) also observed the effect of clarification by centrifuge on the subsequent crossflow microfiltration. Despite clear effect of centrifugation on reduction of turbidity and bacterial count (Table 4), we didn't observe better improvement on filterability index (data not showed). Practically, centrifugation was not able to obtain a wine ready for a sterile filtration, making necessary in these case a previous tangential filtration. Tables 5 and 6 indicate the performance of tubular ceramic tangential filter on wine not centrifuged and centrifuged, respectively. A significant improvement was observed with a reduction of pressure variation, with a flow rate improved at the end of $54.23 \%$ cycle and a filtration time saving of $38.10 \%$. A further indicator of an improvement of filter performance with centrifuged wine was also the time necessary to have the first automatic wash. The centrifuged wine fil-

Table 3. Parameters of different kinds of wines measured before clarification with disk stack centrifuge (mean and standard deviation data $n=3)$.

\begin{tabular}{|c|c|c|c|c|c|c|c|c|c|c|c|c|}
\hline $\begin{array}{l}\text { Wine type } \\
\text { (Ref) }\end{array}$ & $\begin{array}{l}\text { Description Su } \\
\text { of wine }\end{array}$ & $\begin{array}{l}\text { Suspended } \\
\text { solids } \\
(\% v / v)\end{array}$ & $\begin{array}{l}\text { Turbidity } \\
\text { (NTU) }\end{array}$ & $\begin{array}{c}\text { Total } \\
\text { bacterial } \\
\text { count } \\
\text { (CFU/mL) }\end{array}$ & $\begin{array}{l}\text { Total } \\
\text { colloids } \\
\text { (mg/L) }\end{array}$ & $\begin{array}{c}\text { Total } \\
\text { polyphenols } \\
\text { (mg/L) }\end{array}$ & $\begin{array}{c}\text { Alcohol } \\
(\% \mathrm{v} / \mathrm{v})\end{array}$ & $\begin{array}{l}\text { Sugars } \\
(\mathrm{g} / \mathrm{L})\end{array}$ & $\begin{array}{c}\text { Extracts } \\
\text { (g/L) }\end{array}$ & $\mathrm{pH}$ & $\begin{array}{l}\text { Total } \\
\text { acidity }\end{array}$ & $\begin{array}{l}\text { Volatile } \\
\text { acidity } \\
(\mathrm{g} / \mathrm{L})\end{array}$ \\
\hline A & $\begin{array}{l}\text { Red wine from } \\
\text { Cabernet/ } \\
\text { Merlot after } \\
\text { ML and racking }\end{array}$ & 0.4 & $1508 \pm 14.2$ & $805 \pm 12.5$ & $695 \pm 2.9$ & $1190 \pm 11.8$ & $12.86 \pm 0.3$ & $0.97 \pm 0.1$ & $24.55 \pm 0.4$ & $3.56 \pm 0.1$ & $4.87 \pm 0.2$ & $0.19 \pm 0.0$ \\
\hline B & $\begin{array}{l}\text { Red wine from } \\
\text { Cabernet/Merlot } \\
\text { after ML } \\
\text { and racking }\end{array}$ & 0.5 & $2883 \pm 11.3$ & $10300 \pm 68.1$ & $753 \pm 22.5$ & $2467 \pm 14.6$ & $12.91 \pm 1.2$ & $1.01 \pm 0.2$ & $30.96 \pm 5.5$ & $3.81 \pm 0.1$ & $4.70 \pm 0.6$ & $0.30 \pm 0.1$ \\
\hline $\mathrm{C}$ & $\begin{array}{l}\text { Rose wine from } \\
\text { different variety } \\
\text { before ML } \\
\text { and two times } \\
\text { racking }\end{array}$ & 0.4 & $2013 \pm 31.4$ & $450 \pm 19.3$ & $287 \pm 2.9$ & $291 \pm 9.9$ & $11.87 \pm 2.5$ & $0.72 \pm 0.1$ & $22.25 \pm 2.1$ & $3.41 \pm 0.0$ & $5.75 \pm 0.1$ & $0.16 \pm 0.1$ \\
\hline D & $\begin{array}{l}\text { White wine } \\
\text { from Viognier; } \\
\text { fermentation } \\
\text { with bentonite } \\
\text { addition, } \\
\text { racking and ageing } \\
\text { on lees }\end{array}$ & 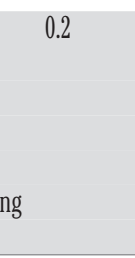 & $394 \pm 4.1$ & $132 \pm 3.7$ & $285 \pm 8.8$ & $277 \pm 5.2$ & $12.94 \pm 2.0$ & $3.46 \pm 0.1$ & $24.40 \pm 0.9$ & $3.53 \pm 0.6$ & $4.92 \pm 0.3$ & $0.18 \pm 0.0$ \\
\hline E & $\begin{array}{l}\text { Red wine } \\
\text { from Cabernet } \\
\text { Sauvignon } \\
\text { fermented with } \\
\text { maceration } \\
\text { of 8-10 days with } \\
\text { staves and chips, } \\
\text { racking and separa } \\
\text { from lees }\end{array}$ & n.a. & $46 \pm 2.1$ & $42 \pm 0.9$ & $864 \pm 12.0$ & $3154 \pm 61.0$ & $13.65 \pm 0.8$ & $2.82 \pm 0.4$ & $31.18 \pm 1.6$ & $3.72 \pm 0.3$ & $4.86 \pm 0.1$ & $0.57 \pm 0.2$ \\
\hline
\end{tabular}

Ref, reference field observation experiment; NTU, nephelometric turbidity unit; $\mathrm{ML}$, malolactic fermentation; $\mathrm{CFU}$, colony-forming unit; n.a., not available. Wine temperature was between 15 and $17^{\circ} \mathrm{C}$. 
tration reaches automatic wash after 175 minutes compared to the 83 minutes in the same conditions with not centrifuged wine. Our observation fields are in line with similar researches in literature, which show an improvement of permeation flux of tangential cross-flow filter with centrifuged wine from 40 to $75 \%$ depending on experimental condition compared to the same wine not centrifuged before. ${ }^{26}$ Results are easily explained considering that large particules and aggregates has an important role on the incidence of fouling. This makes the use of centrifuge, before the cross-flow filtration, strictly reccomended not only in wine application. Similar effects are reported also with centrifugal technology applied in other fermented beverage as beer ${ }^{28}$ or in other application as biomedical. ${ }^{29}$ All analysed wines did not show any effect on total polyphenols and total colloids (data not showed) confirming that colloids are dispersed solids with dimensions between 0.002 and 0.1 $\mu \mathrm{m}$ and cannot be removed by centrifuge as well as solutes like polyphenols.

During the winemaking process, the contact of oxygen with wine is a very important topic, due to his impact on wine quality. The level of dissolved oxygen during different technological treatments (pumping, filtration, racking and, obviously, centrifugation) must be taken under serious monitoring by winemakers.

Dissolved oxygen during wine centrifugation is strictly dependent on bowl design. Figure 4 shows the influence of operational parameters of an open bowl centrifuge on dissolved oxygen of wine type A (Table 3 ). The amount is decreased by the increasing of flow rate and of counter pressure at liquid outlet with a more important effect of this last one. Trend is explained by the fact that with higher counter pressure or higher flow rate, with all the rest of fixed parameters in an open bowl centrifuge, the bowl is more filled by liquid with subsequent less possibility of contact with air. The operator should adjust flow rate and counter pressure with the intention to reduce dissolved oxygen and to balance it with a variation of the performance on clarification, remembering that clarification efficiency is reduced by the increasing of flow rate. The general level of dissolved oxygen with an open bowl centrifuge design is similar to the values reported in the literature and it is considered as a significant introduction of oxygen, if we compare it to other technologies as filtration.22

The oxygen dissolved in wine by centrifugal technology is drastically reduced by bottom feed full hermetic bowl. Dissolved oxygen with a bottom feed bowl design is normally below 20 ppb values (Figure 5) measured on wine type D (Table 3). The slightly increase of the observed dissolved oxygen, in relation with the flow rate in a bottom feed hermetic bowl, is probably due to centrifugal pump used for feeding not really capable to maintain the proper liquid pressure at outlet. It is preferable



Figure 4. Influence of counter pressure on dissolved oxygen during clarification of red wine (Ref. A) through a centrifuge top feed open (mean data $n=3)$.

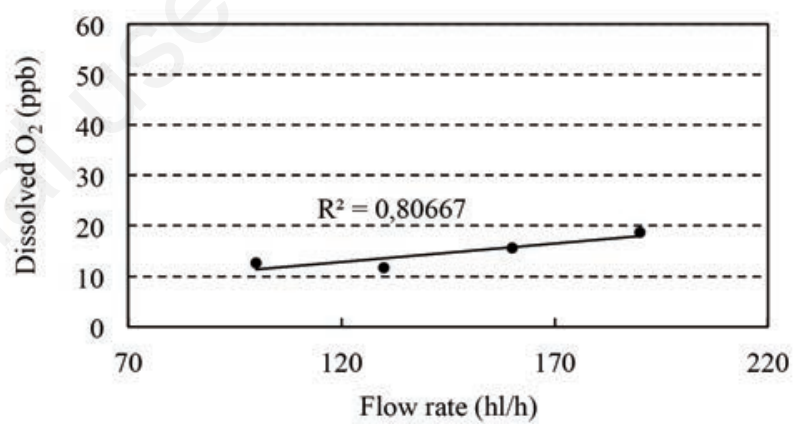

Figure 5. Influence of flow rate on dissolved oxygen during clarification of white wine (Ref. D) through a centrifuge bottom feed full hermetic and counter pressure of 5 bar (mean data $n=3$ ).

Table 4. Wine clarification results with different types of wine, centrifuge and operational conditions (mean and standard deviation data $\mathbf{n}=3$ ).

\begin{tabular}{|c|c|c|c|c|c|c|}
\hline $\begin{array}{l}\text { Wine type } \\
\text { (Ref) }\end{array}$ & Bowl's design & $\begin{array}{l}\text { Flow rate } \\
(\mathrm{hL} / \mathrm{h})\end{array}$ & $\begin{array}{l}\text { Turbidity } \\
\text { (NTU) }\end{array}$ & $\begin{array}{l}\text { Total bacterial count } \\
\text { (CFU/mL) }\end{array}$ & $\begin{array}{l}\text { Reduction of turbidity } \\
\qquad(\%)\end{array}$ & $\begin{array}{l}\text { Reduction of bacterial count } \\
\qquad \%)\end{array}$ \\
\hline A & Top feed open & 20 & $31.4 \pm 4.1$ & $145 \pm 4.1$ & 97.9 & 82.0 \\
\hline A & Top feed open & 30 & $31.4 \pm 0.9$ & $200 \pm 7.3$ & 97.9 & 75.1 \\
\hline A & Top feed open & 50 & $32.1 \pm 0.3$ & $290 \pm 3.3$ & 97.9 & 64.0 \\
\hline B & Top feed open & 40 & $157.3 \pm 6.4$ & $210 \pm 2.0$ & 94.5 & 98.0 \\
\hline B & Top feed open & 60 & $167.0 \pm 7.9$ & $220 \pm 8.0$ & 94.2 & 98.0 \\
\hline B & Top feed open & 80 & $172.3 \pm 18.0$ & $190 \pm 9.6$ & 94.0 & 98.1 \\
\hline $\mathrm{C}$ & Top feed hermetic seal & 50 & $6.5 \pm 0.1$ & $80 \pm 2.8$ & 99.7 & 82.2 \\
\hline $\mathrm{C}$ & Top feed hermetic seal & 90 & $7.6 \pm 0.3$ & $60 \pm 0.3$ & 99.6 & 86.7 \\
\hline $\mathrm{C}$ & Top feed hermetic seal & 130 & $8.8 \pm 0.2$ & $40 \pm 0.7$ & 99.6 & 91.1 \\
\hline D & Bottom feed full hermetic & 130 & $7.3 \pm 0.1$ & $31 \pm 1.0$ & 98.1 & 76.5 \\
\hline D & Bottom feed full hermetic & 190 & $12.5 \pm 0.7$ & $29 \pm 0.5$ & 96.8 & 78.0 \\
\hline D & Bottom feed full hermetic & 220 & $12.9 \pm 0.1$ & $27 \pm 0.3$ & 96.7 & 79.5 \\
\hline E & Bottom feed full hermetic & 160 & $13.0 \pm 0.2$ & 3 & 71.7 & 92.9 \\
\hline
\end{tabular}


use volumetric pump with correct outlet pressure to feed bottom feed hermetic centrifuge design. As explained in paragraph 4 , it is necessary to intermittently open the bowl of centrifuges to discharge solids. Dissolved oxygen measured during the discharge step is higher than that measured during the regular centrifugation process. During the discharge of the bowl, dissolved oxygen is variable form 0.22 to $5.15 \mathrm{ppm}$ depending on bowl design and operational parameters. In any case, due to the fact that the discharge of solids is very fast (fraction of second) and its frequency is every 10-15 minutes, it does not significantly influence the total dissolved oxygen in wine during the production.

Design improvements conducted on the centrifuge technology allow a drastic reduction of dissolved oxygen to minimal values, absolutely comparable to filtration techniques and/or other technologies used in the cellar, or even better.22,23

\section{Conclusions}

Clarification is an essential winemaker practice for the attribution of the quality to each wine category. Advances made in recent times to improve the technological application, were mainly dedicated to the introduction of recent cross-flow microfiltration techniques. Despite that, cross flow microfiltration tech-

Table 5. Performances of tangential filtration of non-previously centrifuged red wine type $E$ (mean and standard deviation data $n=3$ ).

\begin{tabular}{lcccc}
$\begin{array}{l}\text { Process step/time } \\
(\mathrm{min})\end{array}$ & $\begin{array}{c}\text { Filtered volume } \\
(\mathrm{hL})\end{array}$ & $\begin{array}{c}\Delta \mathrm{P} \\
(\mathrm{bar})\end{array}$ & $\begin{array}{c}\text { Flow rate } \\
(\mathrm{L} / \mathrm{h})\end{array}$ & $\begin{array}{c}\text { Turbidity } \\
\text { (NIU) }\end{array}$ \\
\hline 20 & 7.01 & 0.6 & 1800 & $1.8 \pm 0.1$ \\
30 & 10.07 & 0.7 & 1800 & $2.1 \pm 0.3$ \\
\hline 44 & 13.71 & 0.8 & 1800 & $2.8 \pm 0.0$ \\
60 & 18.21 & 0.95 & 1800 & $3.0 \pm 0.1$ \\
\hline 71 & 22.16 & 1.03 & 1800 & $2.7 \pm 0.2$ \\
$83-$ Automatic wash (hot/cold) & 25.46 & 0.66 & 1800 & $1.9 \pm 0.1$ \\
\hline 165 & 50.43 & 2.00 & 1800 & $2.5 \pm 0.4$ \\
181 & 54.77 & 2.00 & 1800 & $2.6 \pm 0.2$ \\
\hline 194 & 58.04 & 2.00 & 1800 & $2.8 \pm 0.2$ \\
217 & 63.94 & 2.00 & 1800 & $1.9 \pm 0.0$ \\
\hline 244 & 71.06 & 2.00 & 1800 & $2.3 \pm 0.3$ \\
$1260-$ (end of cicle) & 330.0 & 0.00 & 1571 & $2.9 \pm 0.3$ \\
\hline
\end{tabular}

P, pressure; NTU, nephelometric turbidity unit. Wine temperature was between 12.6 and $13.7^{\circ} \mathrm{C}$.

Table 6. Performances of tangential filtration of previously centrifuged red wine type $\mathrm{E}$ (mean and standard deviation data $n=3$ ).

\begin{tabular}{lcccc}
$\begin{array}{l}\text { Process step/time } \\
(\mathrm{min})\end{array}$ & $\begin{array}{c}\text { Filtered volume } \\
(\mathrm{hL})\end{array}$ & $\begin{array}{c}\Delta \mathrm{P} \\
(\mathrm{bar})\end{array}$ & $\begin{array}{c}\text { Flow rate } \\
(\mathrm{L} / \mathrm{h})\end{array}$ & $\begin{array}{c}\text { Turbidity } \\
(\mathrm{NIU})\end{array}$ \\
10 & 2.93 & 0.38 & 1860 & $0.20 \pm 0.0$ \\
21 & 6.96 & 0.62 & 1920 & $0.22 \pm 0.0$ \\
\hline 31 & 9.74 & 0.59 & 1920 & $0.17 \pm 0.0$ \\
40 & 12.66 & 0.57 & 1920 & $0.16 \pm 0.1$ \\
\hline 116 & 44.28 & 1.23 & 2280 & $0.18 \pm 0.1$ \\
128 & 49.63 & 1.26 & 2280 & $0.19 \pm 0.2$ \\
\hline 138 & 53.88 & 1.35 & 2340 & $0.16 \pm 0.0$ \\
152 & 60.70 & 1.57 & 2340 & $0.17 \pm 0.2$ \\
\hline 165 & 66.48 & 1.88 & 2400 & $0.21 \pm 0.1$ \\
$175-$ Automatic wash (hot/cold) & 71.40 & 0.65 & 2400 & $0.19 \pm 0.3$ \\
\hline 186 & 76.56 & 0.78 & 2460 & $0.22 \pm 0.1$ \\
192 & 79.40 & 0.82 & 2460 & $0.16 \pm 0.0$ \\
\hline $780-$ (end of cicle) & 315 & 0.00 & 2423 & $0.19 \pm 0.0$ \\
\hline
\end{tabular}

P, pressure; NTU, nephelometric turbidity unit. Wine temperature was between 12.6 and $13.7^{\circ} \mathrm{C}$.

niques are still hampered by the technological and economical barriers induced by membrane fouling. Simoultaneusly, we have also carried out important advances on improving the performance of centrifugal technology with a special focus on gentle wine treatment, minimal dissolved oxygen and significant reduction of energy consumption, helping to dispel old beliefs on a technique considered as traditional. The separation duties handled by centrifugal technology are many and very important (Table 2). Some of them have long been known while some are new, as the pre-clarification with centrifuge for a significant improvement of the cross-flow filter performances through fouling reduction. Latest introduction of bottom feed design ensure minimal dissolved oxygen together with optimized energy consumption and gentle wine treatment, More opportunities are possible in the future by centrifugal technology applied in combination with fining agents, as already successfully investigated for the removal of haze-froming protein from white wine.$^{30,31}$ From the moment of the invention of centrifuge by Dr. Gustaf De Laval in 1878 , clarification techniques are today still projected to a continuous improvement, able to lead the increase of process capacity as well as wine quality.

\section{References}

1. Beveridge T. Large-scale centrifugation. In: Wilson ID, Adlard ER, Cook M, Poole CF, eds. Encyclopaedia of separation science. London: Academic Press; 2000.

2. Axelsson H, Madsen B. Centrifuges, sedimenting. New York: John Wiley \& Sons; 2012.

3. Ribéreau-Gayon J, Peynaud E. Traité d'Enologie. Composition, transformations et traitements des vins. Paris: Beranger; 1961.

4. Garoglio PG. I separatori centrifughi nell'industria olearia ed enologica. Il Progresso Vinicolo ed Enologico 1939; 168:2575.

5. Fessler JH. The clarification of wine with centrifuge. Part I. Am J Enol Viticult 1951;2:201-4.

6. Fessler JH. Centrifugal clarification of wines versus filtration of wines. Am J Enol Viticult 1953;4:151-5.

7. Nasledov SN. (1951). The clarification of wine with centrifuge. Part II. Am J Enol Viticult 1951;2:205-6.

8. Brennan JG, Grandison AS, Lewis MJ. Separation in food processing. In: Brennan JG, ed. Food processing handbook. Wiley-VCH Verlag GmbH \& Co. KGaA, Weinheim, Germany; 2006. pp 429-512.

9. International Organization of Vine and 
Wine. International code of oenological practices. Paris: Issues; 2016.

10. Ribéreau-Gayon P, Glories Y, Maujean A, Dubourdieu D. Clarifying wine by filtration and centrifugation. In: RibéreauGayon P, Dubourdieu D, Donèche $B$, Lonvaud A, eds. Handbook of enology: the chemistry of wine stabilization and treatments, Vol 2. New York: John Wiley \& Sons; 2006. pp 333-67.

11. Boulton RB, Singleton VL, Bisson LF, Kunkee R. Principles and practices of winemaking. Amsterdam: Springer Science \& Business Media; 2013.

12. De Vita P, De Vita G. Manuale di meccanica enologica. Milan: Hoepli; 2011.

13. Sokolov VI. Moderne industriezentrifugen. Berlin: VEB Verlag Technik; 1971.

14. Borgström L, Carlsson CG, Inge C, et al. Pressure drop for flow in channels subjected to strong system rotation. Appl Sci Res 1994;53:35-50.

15. El Rayess Y, Albasi C, Bacchin P, et al. Cross-flow microfiltration applied to oenology: a review. J Membrane Sci 2011;382:119.

16. Lonvaud A, Renouf V, Strehaiano P. Microbiologie du vin: bases fondamentales et applications. Paris: Tec \& Doc Lavoisier; 2010.

17. Flanzy C. Oenologie: fondements scientifiques et technologiques. Paris: Tec \& Doc
Lavoisier; 1998.

18. Van Sluyter SC, McRae JM, Falconer RJ, et al. Wine protein haze: mechanisms of formation and advances in prevention. J Agr Food Chem 2016;63:4020-30.

19. Jaeckels N, Meier M, Dietrich $\mathrm{H}$, et al. Influence of polysaccharides on wine protein aggregation. Food Chem 2016;200:3845.

20. Bindon KA, Carew AL, Mierczynska-Vasilev A, et al. Characterization of macromolecular complexes in red wine: composition, molecular mass distribution and particle size. Food Chem 2016;199:838-46.

21. Mierczynska-Vasilev A, Smith PA. Current state of knowledge and challenges in wine clarification. Aust $\mathrm{J}$ Grape Wine $\mathrm{R}$ 2015;21:615-26.

22. Castellari M, Simonato B, Tornielli GB, et al. Effects of different enological treatments on dissolved oxygen in wines. Ital $\mathrm{J}$ Food Sci 2004;16:387-97.

23. Vidal JC, Dufourcq T, Boulet JC, Moutounet $M$. Les apports d'oxygène au cours des traitements des vins. Bilan des observations sur site, lère partie. Rev Fr Oenol 2001;190:24-31.

24. Czekaj P, López F, Güell C. Membrane fouling during microfiltration of fermented beverages. J Membrane Sci 2000;166:199212.

25. Vernhet A, Cartalade D, Moutounet M.
Contribution to the understanding of fouling build-up during microfiltration of wines. J Membrane Sci 2003;211:357-70.

26. Escudier JL, Moutounet M, Vernhet A. Application des membranes dans la filière oenologique. Tech Ingen Agroaliment 2000;2000:TIP700WEB.

27. Grangeaon A, Vernhet A. Innovations dans la microfiltration des vins: membranes et procédés. Rev Oenol Tech Vit Oenol 2004;113:37-40.

28. Cimini A, Marconi 0, Perretti G, et al. novel procedure for lager beer clarification and stabilization using sequential enzymatic, centrifugal, regenerable PVPP and crossflow microfiltration processing. Food Bioprocess Technol 2014;7:3156-65.

29. Axelsson H. Cell separation, centrifugation. In: Flickinger MC, Drew SW, eds. The encyclopedia of bioprocess technology: fermentation, biocatalysis, and bioseparation. New York: John Wiley \& Sons; 2013. pp. 27-48.

30. Muhlack R, Nordestgaard S, Waters EJ, et al. In-line dosing for bentonite fining of wine or juice: contact time, clarification, product recovery and sensory effects. Aust J Grape Wine R 2006;12:221-34.

31. Nordestgaard S, Chuan YP, O'Neill B, et al. In-line dosing of white wine for bentonite fining with centrifugal clarification. Am J Enol Viticult 2007;58:283-5. 